\title{
NETWORK DESIGN DECISION IN A CLOSED LOOP SYSTEM: LESSON LEARNED FROM ELECTRICITY DISTRIBUTION POLICY IN INDONESIA
}

\author{
Hidajat Hendarsjah*1, Wisnu Untoro*), and Reza Rahardian*) \\ *) Management Study Program, Faculty of Economics and Business, Universitas Sebelas Maret \\ Jl. Ir. Sutami 36A, Surakarta, Jawa Tengah
}

\begin{abstract}
The article described the difficulty to spot specific suppliers that feed the targeted customers in a closed-loop supply chain. When managers had difficulties in identifying the role of suppliers in a supply chain network, several possible situations might appear, such as redundant supply that led to both over and undersupply situations. The article also portrayed a course of an evaluative process underlies the network design decisions in a closed-loop electricity supply system. The case research, as presented in the article, was based on an archival data examination, literature review, structured interviews, and observations on the field operations of the electricity distribution system in Indonesia's main islands. The research findings revealed that the distribution network within the closed-loop supply chain system was suggested to implement two stages decisions; started with local optimization analysis and followed by unified solution among all local optimal solutions. Such an approach arguably would reduce redundant supply as well as minimizing both over and undersupply in the system. For practical implications the article demonstrated the possibility of drawing the false conclusion when transmission costs were ignored in the supply chain-design decision analysis, as exhibited in the Indonesia electricity supply network.
\end{abstract}

Keywords: case research, closed loop supply chain, distribution channel, supply chain management, supply network

\begin{abstract}
Abstrak: Artikel ini menjabarkan kompleksitas yang dihadapi oleh para manajer ketika menetapkan konfigurasi pemasok yang dapat memenuhi permintaan konsumen dalam suatu sistem rantai pasokan tertutup. Masalah spesifik yang dihadapi oleh para manajer pada situasi tersebut adalah urusan pasokan berlebih maupun pasokan yang defisit. Untuk mengendalikan masalah-masalah tersebut artikel ini juga mendeskripsikan perlunya proses evaluatif dalam pengambilan keputusan pada sistem rantai pasokan tertutup. Demi mendapatkan solusi tersebut, penelitian berbasis kasus digunakan untuk mengelaborasi proses pengambilan keputusan yang dapat menghasilkan luaran yang efektif secara sistemik. Hasil penelitian menunjukkan bahwa keputusan dua tahap, yang diawali dengan optimasi di wilayah-wilayah regional dan diikuti dengan penyatuan optimasi untuk seluruh sistem rantai pasokan tertutup dapat mengurangi terjadinya pasokan berlebih maupun pasokan yang defisit. Pada tataran implikasi praktis, artikel ini juga mengulas terdapatnya peluang bagi para manajer untuk salah menyimpulkan tentang kualitas kinerja suatu sistem rantai pasokan tertutup, ketika mereka mengabaikan biaya transmisi, sebagaimana dihadapi pada jaringan distribusi listrik di Indonesia.
\end{abstract}

Kata kunci: case research, closed loop supply chain, distribution channel, supply chain management, supply network

\footnotetext{
${ }^{1}$ Corresponding author:

Email: h.hendarsjah@staff.uns.ac.id
} 


\section{INTRODUCTION}

Distribution always has an essential role in supply chain. Following Chopra and Meindl (2016), the article defines the term "distribution" as the steps taken to move and store a product from the supplier stage to a customer stage in the supply chain. Further, Chopra and Meindl (2016) suggest that there are two key decisions to be considered when designing a distribution network; will the product be delivered to the customer location or picked up from a prearranged site, and will the product flow through an intermediary. Those decision sets are easier to implement when managers are dealing with open loop systems, that is when the output condition is not fed back in the system (Rakhman et al. 2018; Chopra, 2003).

Distribution planning decisions may turn into complex activities when ones are faced with closed loop supply chain (CLSC) systems, in which some or all of its output is used as its input (Welts and Seitz, 2005). As compared to the decision making within open loop system, the main problems that may be found in the closed loop supply chain system is the difficulty to spot specific suppliers that feed the targeted customers (Winkler, 2011; Souza, 2013). When managers have difficulties to identify the role of suppliers in supply chain network, several possible situations may appear, such as redundant supply that leads to both over and under supply situations. To elaborate the phenomenon, the article shed light on the Indonesia's main islands electric power distribution system servicing Java and Bali areas.

Closed Loop Supply Chain, as compared to forward supply chain, has a convergent structure (Fleischmann et al. 1997), as a consequence in the case of direct reuse of product (as it is in the electricity distribution), no additional production processes has to be taken into account. In the circumstances, a focus on inventory and distribution-collection decision may outweigh the importance of production planning decision (Fleischmann et al. 1997). This implies that a CLSC differs with the regular production activity, in addition it may involve different levels of coordination, and ultimately it may impose constraints on the potential actors involved in reuse activities.

Activitiesofactorsinvolvedinreuseactivities, collection, testing, and reprocessing, may set constraints on the possibility of integrating forward and reverse supply chain (Fleischmann et al. 1997; Morana and Seuring, 2011). Thus the implied decisions in a CLSC will be: who are the actors in the reverse distribution channel; which functions have to be carried out in the reverse distribution channel and where; and what is the relation between the forward and the reverse distribution channel (Fleischmann et al. 1997). These may lead to routing problem as the collection and delivery may require different handling. This complicating characteristic of a CLSC may require case method to elaborate and to describe the problem. Guide et al. (2003) argued that when dealing with CLSC, the major strength of the case method is theory building and identifying new variables and relationships not envisaged in the original research. Following these logics, we employ a single case method to deal with the Indonesian JavaBali electricity distribution problem.

The previous discussion indicates that when one designs a CLSC system, as in the Indonesian Java-Bali electricity distribution network, it is possible to deal with several factors, (1) it has closed loop system, in which the output quantity does have effect on the input to the supply chain system, (2) there are (or may be existed) various capacitated power plants, and (3) to keep the system efficient given the capacitated supply, then it is reasonable to establish the power plant utilization rule or the priority rule. The latter characteristic of the CLSC system may yield a redundant supply when priority rule policy is the only single strategy to meet demand in the network. We argue that the relevant problem definition when dealing with such circumstances is how to build an efficient system-wide distribution system given the embedded characteristics of the supply chain (Table 1). Dealing with redundant supply will be a focal issue if ones work with closed loop supply chain.

Table 1. Addressing redundant supply in a closed loop supply chain

\begin{tabular}{lccc}
\hline Case & Lower Cost Power Plant & Redundant Supply & Efficiency \\
\hline Existing priority rule policy (if any) & Yes & Probably higher & Not known \\
Other decision model (To be the focus of the study) & Yes & Probably lower & Not known \\
\hline
\end{tabular}




\section{METHODS}

The study was conducted in Indonesia, and a case study research was established to collect evidence and elaborate the relevant information (Yin, 1981, 2009; Guide, 2000; Fleischmann et al. 1997; Fleishmann et al. 2000). A mixed method approach was utilized to explore the unique phenomenon of the CLSC at the Indonesian Java-Bali electricity distribution system. In the qualitative stage of analysis, the official data and field operator comments were main data source of the study (Yin, 1981, 2009; Corley and Gioia, 2004; Gioia et al. 2012). Specifically the data collection was conducted through focused-group discussion, in-depth interview, and collecting public use files such as the government regulations and statistical data. The informants were 19 middle-level officers of the Indonesia Ministry of Energy and Mineral Resources (ESDM), and 2 officers and a General Manager of PT PLN Control Center / P2B (a state owned company in electric power transmission and distribution system). The interview and focusedgroup discussion were conducted to confirm the archival data of two main information: (1) how to establish the Java-Bali electricity distribution system, and (2) how to elaborate the implementation of the government regulations on the electricity distribution system.

To elaborate on how the supply chain configuration was established, series of open-ended questions were developed: (1) what is the role of each facility in the supply chain, and (2) how do the facilities support each other. In addition, questions to address the current strategy of matching electricity supply with demand were (1) how to define demand, and (2) how to deploy facilities to meet demand. Results then were analyzed using perspectives on efficient supply chain. Framework of the study is depicted in Figure 1.

After we obtained sufficient information regarding to the possibility of establishing more efficient supply configuration, as indicated in the qualitative stage of analysis, we then matching several quantitaive tools to construct a particular supply chain model that may fit to the purpose. When dealing with the scattered capacitated supplies as well as demand points in a supply chain system (as indicated in the electricity distribution system at the Java-Bali network), we employed (1) Gravity Location model in identifying the geographic location where the potential sites (for both power plants and demand points) may be considered, and (2) Linear Programming, if there is possibility to minimize overall costs, in the form of linear function, in the CLSC system.

Following Heizer et al. (2017) in the Gravity Location model, if $(x, y)$ is the location selected for the facility, the distance dn between the facility at location $(\mathrm{x}, \mathrm{y})$ and the supply source or demant point $\mathrm{n}$ is given by:

$$
d_{n}=\left[\left(x-x_{n}\right)^{2}+\left(y-y_{n}\right)^{2}\right]^{1 / 2}
$$

and the total distribution cost (in our case is the electricity transmission cost) is given by :

$$
\mathrm{TC}=\sum_{\mathrm{n}=1}^{\mathrm{k}} \mathrm{d}_{\mathrm{n}} \mathrm{D}_{\mathrm{n}} \mathrm{F}_{\mathrm{n}} \text { (Equation 1) }
$$

Description: $x_{n}, y_{n}$ (coordinate location of either a demand point or supply source $n$ ); $F_{n}$ (transmission cost between the facility and either demand point or supply source $n$ ); $D_{n}$ (quantity to to be transmitted). The optimal location is one that minimize the total TC in Equation 1.

Besides locating the facilities, as obtained from the Gravity Location model, the next decision is how demand points are allocated to facilities. The goal is to allocate the demand from different markets to the various power plants to minimize the total cost of facilities and transmission. The problem is formulated as the following linear program (Chopra and Meindl, 2016):

$$
\operatorname{Min} \sum_{\mathrm{i}=1}^{\mathrm{n}} \mathrm{f}_{\mathrm{i}}+\sum_{\mathrm{i}=1 \mathrm{j}=1}^{\mathrm{n}} \sum_{\mathrm{c}_{\mathrm{ij}} \mathrm{x}_{\mathrm{ij}}}
$$

Description: $\mathrm{n}$ (Number of power plant locations); $\mathrm{m}$ (Number of demand points); $f_{i}$ (Power generating cost of keeping power plant $\mathrm{i}$ open); $\mathrm{c}_{\mathrm{ij}}$ (Cost of producing and delivering one unit from power plant $i$ to demand point $\mathrm{j}) ; \mathrm{y}_{\mathrm{i}}(1$ if power plant is located at site $\mathrm{i}, 0$ otherwise); $\mathrm{x}_{\mathrm{ij}}$ (Transmitted electricity from plant site $\mathrm{i}$ to demand point $\mathrm{j}$ ). 


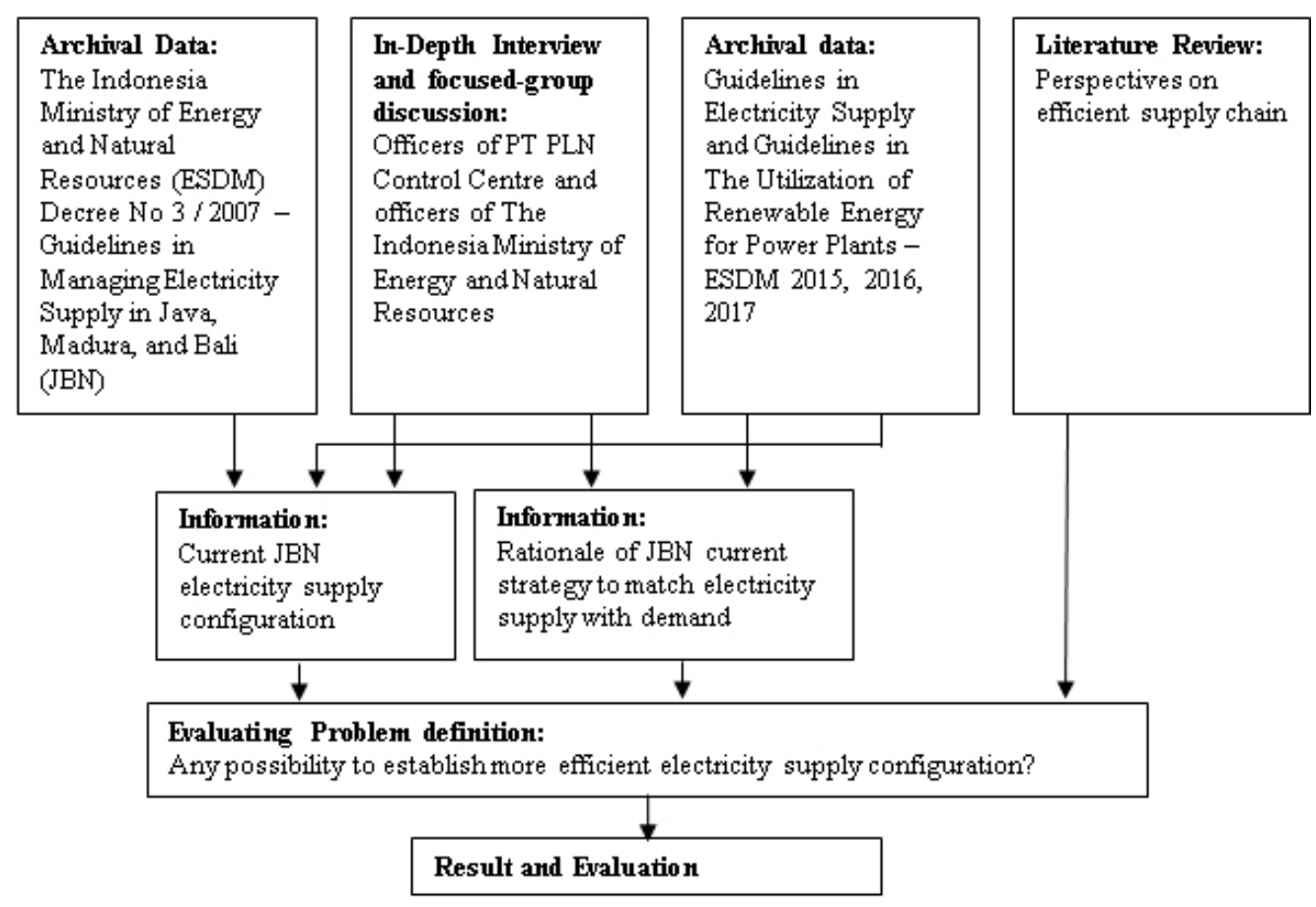

Figure 1. Research framework

\section{RESULTS}

Supply chain network design decisions include the assignment of four things; facility role (what activities are performed at each capacity?), facility location, capacity allocation, and market and supply allocation (what demand points should each facility serve?). In addition, the supply chain design decisions may be utilized to decrease supply chain cost as well as to achieve higher responsivenes. This is because, from the outset, the supply chain configuration can be determined and the constraints can be set within which the other supply chain drivers (Chopra and Meindl, 2016). Conclusively the aim of network design decisions are expectedly to achieve balance between responsiveness and efficiency that best supports the organization's competitve strategy. Such perspective gives clear comprehension in addressing the main issues to elaborate supply chain characteristics as in the Indonesia electric power distribution system. Table 2 provides the case study evidence portraying the supply chain configuration in Java-Bali network (JBN), which comprises of the archival data and the corresponding comments from focused-group discussion and in-depth interview.

As implied in Table 2, in general, the electricity supply chain in Java-Bali network comprises of three main activities: power generation, transmission and distribution. Each activities are managed by different business entities (The Indonesia Ministry of Energy and Natural Resources, 2007). Power generators are managed by three government-owned companies (PT Perusahaan Listrik Negara (PT PLN), PT Indonesia Power and PT Pembangkitan Jawa Bali) and several minor supplies under Power Purchase Agreements between the government-owned company and private power generators. The transmission and distribution activities are managed by PT PLN Control Center (P2B), with the specific tasks in flowing and controlling the electric supply from all power generators to the assigned distribution points in the system (Figure 2).

To maintain the continuity of electricity supply, the control center (P2B) and the power generators are always in coordinating modes: which power generators should operate in their hourly full capacity and which are to operate in lower capacity. Currently such activities are assumed to be effective as electric demand in the JBN area is triggered by two stable activities: (1) high manufacturing activities in Jakarta and Banten area, and (2) household activities in the rest area within JBN. The power demand on weekdays and on Saturday are not quite diverse, but it has different characteristic on Sunday and on holidays: low demand in the afternoon lasts longer. Highest demand on Sunday are only $89 \%$ of the system capacity, and highest demand on holidays are even lower than on Sunday (The Indonesia Ministry of Energy and Mineral Resources, 2015, 2016). 
Table 2. Supply chain configuration in the Java-Bali network

\begin{tabular}{|c|c|c|}
\hline Archival Data & $\begin{array}{l}\text { Comments from Focused-Group Discussion and In-Depth } \\
\text { Interview }\end{array}$ & Main Issues \\
\hline $\begin{array}{l}\text { The Indonesia Ministry of Energy } \\
\text { and Natural Resources Decree No. } 3 \text { / } \\
\text { 2007: Guidelines in Managing Elec- } \\
\text { tricity Supply in Java, Madura, and } \\
\text { Bali. }\end{array}$ & $\begin{array}{l}\text { "Power generators are managed by three government-owned } \\
\text { companies (PT Perusahaan Listrik Negara (PT PLN), PT In- } \\
\text { donesia Power and PT Pembangkitan Jawa Bali) and several } \\
\text { minor supplies under Power Purchase Agreements between } \\
\text { the government-owned company and private power genera- } \\
\text { tors" }\end{array}$ & $\begin{array}{l}\text { Role of facilities } \\
\text { in the Java-Bali } \\
\text { network }\end{array}$ \\
\hline $\begin{array}{l}\text { "The electricity supply in Java-Bali } \\
\text { network comprises of three activities: } \\
\text { power generation, transmission, and } \\
\text { distribution" }\end{array}$ & $\begin{array}{l}\text { "The control center (P2B) and the power generators are al- } \\
\text { ways in coordinating modes: which power generators should } \\
\text { operate in their hourly full capacity and which are to operate } \\
\text { in lower capacity" }\end{array}$ & \\
\hline $\begin{array}{l}\text { The Indonesia Ministry of Energy } \\
\text { and Natural Resources 2015, 2016: } \\
\text { Guidelines in Electricity Supply in } \\
2015-2025 \text {. }\end{array}$ & $\begin{array}{l}\text { "Electric demand in the JBN area is mainly triggered by two } \\
\text { stable activities: (1) high manufacturing activities in Jakarta } \\
\text { and Banten area, and (2) household activities in the rest area } \\
\text { within JBN" }\end{array}$ & $\begin{array}{l}\text { Triggers of } \\
\text { demand }\end{array}$ \\
\hline $\begin{array}{l}\text { "Highest demand on Sunday are only } \\
89 \% \text { of the system capacity, and high- } \\
\text { est demand on holidays are even lower } \\
\text { than on Sunday" }\end{array}$ & $\begin{array}{l}\text { "The substations within the JBN system control the electric } \\
\text { flow from one transmission line to other transmission lines, } \\
\text { which is then distributed to the consumers or demand points } \\
\text { after the electric voltage is lowered" }\end{array}$ & \\
\hline $\begin{array}{l}\text { "The JBN system has } 22,110 \mathrm{~km} \text { of } \\
\text { high-voltage transmission lines and } \\
431,035 \mathrm{~km} \text { of low-voltage distribution } \\
\text { lines" }\end{array}$ & $\begin{array}{l}\text { "The control center (P2B) should plan an efficient operations } \\
\text { management to obtain the lowest possible cost of power gen- } \\
\text { eration that meeting the forecasted demand" }\end{array}$ & \\
\hline
\end{tabular}

\begin{tabular}{|c|c|c|c|}
\hline $\begin{array}{l}\text { Electric flow } \\
\text { from power } \\
\text { generators }\end{array}$ & $\begin{array}{l}\text { Electric voltage is } \\
\text { raised to } 500 \mathrm{kV} \text { at } \\
\text { high-voltage } \\
\text { substations (HVS) }\end{array}$ & $\begin{array}{l}\text { The high-voltage } \\
\text { electricity flows to } \\
\text { JBN transmission } \\
\text { system }\end{array}$ & $\begin{array}{c}\text { Electric voltage is } \\
\text { lowered at HVS and } \\
\text { flows to distribution or } \\
\text { demand points }\end{array}$ \\
\hline
\end{tabular}

Figure 2. Electricity Supply Chain at JBN Area

Once the assigned power stations supply the electricity into the system, the substations within the JBN system plays pivotal role in controlling the electric flow from one transmission line to other transmission lines, which is then distributed to the consumers or demand points after the electric voltage is lowered. In supplying the electric power to the consumers, the JBN system has $22,110 \mathrm{~km}$ of high-voltage transmission lines and $431,035 \mathrm{~km}$ of low-voltage distribution lines (The Indonesia Ministry of Energy and Mineral Resources, 2015, 2016). To accomplish the power distribution efficiently, the control center (P2B) should plan an efficient operations management to obtain the lowest possible cost of power generators that meet the forecasted demand, while considering various constraints in the network as well as standard quality of the services.

Table 3 portrays evidence derived from both archival and in-depth interview data showing the current supply strategy to match supply with demand. It also describes on how facilities deploy their roles in the network. Table 3 reveals a "generic" policy of electric supply at the JBN. In matching power supply with demand, the control center (P2B) and the power generators regularly hold coordination meetings to acquire two main information: annual electric utilization in the system and forecasted annual electricity demand. The power utilization is measured in half-an hour utilization, which is derived from annual trends of electric utilization. On 
the other hand, the annual electricity demand is computed based on the assumption of the selected economic factors (demand for business, households and public sectors) and trends in population growth. In determining the supply allocation among its targeted consumers, the control center (P2B) performs series of analysis semi annually to estimate monthly supply capacity of each power generator, estimating utilization plan for each generator, estimating the energy price trends, and estimating the unmet consumer demand.

Based on the demand analysis, the control center (P2B) originates priority rule to run power plants in the JBN system to meet the targeted demand (The Indonesia Ministry of Energy and Mineral Resources, 2015, 2016, 2017). Such priority rule is to seek the lowest possible power generating costs of the available plants. Top priority is given to power plants fueled by renewable energy (i.e. micro-hydro and geothermal power plants) - that is, they have lower operating costs, followed by coal (electric steam power plant), natural gas and hydroelectric power plant (The Indonesia Ministry of Energy and Mineral Resources, 2015, 2016, 2017). This arrangement seems easy to implement, but in a closed loop system, once the electric power flows to the system, tracing back which power plants are supplying the generated power at certain distribution points is difficult to recognize. The next issue is when wider coverage of electric supply becomes main priority of the JBN policy as currently intended by the Indonesia government. Implementing the priority rules in a closed loop supply chain network may lead to supply redundancy of the power plants, that possibly causes over or under supply. The following sections in the article will discuss the arguments.
Planning a distribution network design in a closed loop system will be very time consuming when the corresponding supply chain has plenty of suppliers and consumers as in the JBN electricity network in Indonesia. Following Heizer et al. (2017), to deal with the situation, members of the chain are inclined to focus on minimizing immediate cost based on their limited knowledge, that is, the local optimalization strategy. Analogically when the JBN is currently divided into five areas of distribution points, (1) Jakarta and banten, (2) West Java, (3) Central Java, (4) East Java and (5) Bali (The Indonesia Ministry of Energy and Mineral Resources, 2007, 2015, 2016), there will be five local optimals to obtain. Unfortunately when each locals optimize their areas, then slight upturns in demand are overcompensated for because no one wants to be caught short. Whereas slight downturns are overcompensated for because no one wants to be caught over supplied. In other words, the fluctuations are predictably magnified in both situations (Heizer et al. 2017). This implies that single solution model by establishing the five local optimals (as currently implemented through priority rule policy) is not efficient to gain an integrative system-wide solution. Thus the next possible recommended action, we call it the second stage, is to consolidate results or solutions derived from local optimalization stage. Two focal decisions in the second stage are finding more efficient facilities as well as reallocating the assigned facilities to avoid redundant supply as well as minimizing over or under supply of the facilities.

Table 3. The JBN Supply Strategy

\begin{tabular}{|c|c|c|}
\hline Archival Data & $\begin{array}{l}\text { Comments from Focused-Group Discussion and } \\
\text { In-Depth Interview }\end{array}$ & Main Issues \\
\hline $\begin{array}{l}\text { The Indonesia Ministry of Energy and Natural } \\
\text { Resources Decree No. } 12 \text { / 2017: Guidelines in the } \\
\text { Utilization of Renewable Energy for Power Plants. } \\
\text { "The control center (P2B) originates priority rule } \\
\text { to run power plants in the JBN system to meet } \\
\text { the targeted demand. Such priority rule is to seek } \\
\text { the lowest power generating costs of the available } \\
\text { plants" }\end{array}$ & $\begin{array}{l}\text { "The control center (P2B) performs series of } \\
\text { analysis semi annually to estimate monthly sup- } \\
\text { ply capacity of each power generator, estimating } \\
\text { utilization plan for each generator, estimating the } \\
\text { energy price trends, and estimating the unmet } \\
\text { consumer demand" } \\
\text { "Priority rule is the official policy to distribute } \\
\text { electricity in the network" }\end{array}$ & $\begin{array}{l}\text { JBN strategy in } \\
\text { matching supply } \\
\text { with demand }\end{array}$ \\
\hline $\begin{array}{l}\text { "Top priority is given to power plants fueled by } \\
\text { renewable energy (i.e. micro-hydro and geothermal } \\
\text { power plants) - that is, they have lower operat- } \\
\text { ing costs, followed by coal (electric steam power } \\
\text { plant), natural gas and hydroelectric power plant" }\end{array}$ & $\begin{array}{l}\text { "At this moment we don't have any idea on trans- } \\
\text { mission cost" }\end{array}$ & \\
\hline
\end{tabular}


The required information to establish the two stages of analyses are (1) regional demand, (2) the regional configuration of power plants, (3) the desirable potential power plants to serve the network (including the distribution and transmission capacity), and (4) the generating capacity of each power plant. Given the required information and the proposed analytical stages, decisions shall be organized in an evaluative basis. To accomplish the integrative solution, we propose deterministic model at the first stage to find the five local optimals, and is followed by heuristic approach to obtain system-wide solution at the second stage (Chopra and Sodhi, 2004).

The deterministic model is employed as it is used to evaluate a current network design for the five local optimals so that a "base case" can be established against which optimized network design may be compared (Ballou, 2004). Thus modeling the local network usually involves replicating the cost structures, constraints, and other factors that represent the network in a reasonable manner. The use of both linear programming and gravity method are necessary in determining the local power supply configuration and to pin-point precise locations of the related facilities (i.e. the High Voltage Sub-stations) (Chopra and Meindl, 2016). Output of the deterministic analysis or the "base case" is then used for further evaluative decisions in the next heuristic analysis given the several constraints on the five local distribution areas (Schultmann et al. 2003; Kumar and Yamaoka, 2007). Specifically, the evaluative activity in the heuristic approach can be referred into as any principles or concepts to reduce the average time to search for a solution. They are sometimes referred to as "rule of thumb" that guide problem solving. When applied to problems of allocation, such rule of thumb which is a consequence of insight into the solution process, it is expectedly allow good solutions to be obtained quickly from numerous activities (Ballou, 2004). This approach is also called the fine-tuning activities at the system-wide analysis. Reallocation of power plants utilization with redundant supply is managed through an evaluative decision by considering excess or idle capacity of the existing power plants as indicated from local optimization stage of analysis. Conclusively, a comprehensive analysis to design distribution network within a closed loop supply chain system is depicted in Figure 3.

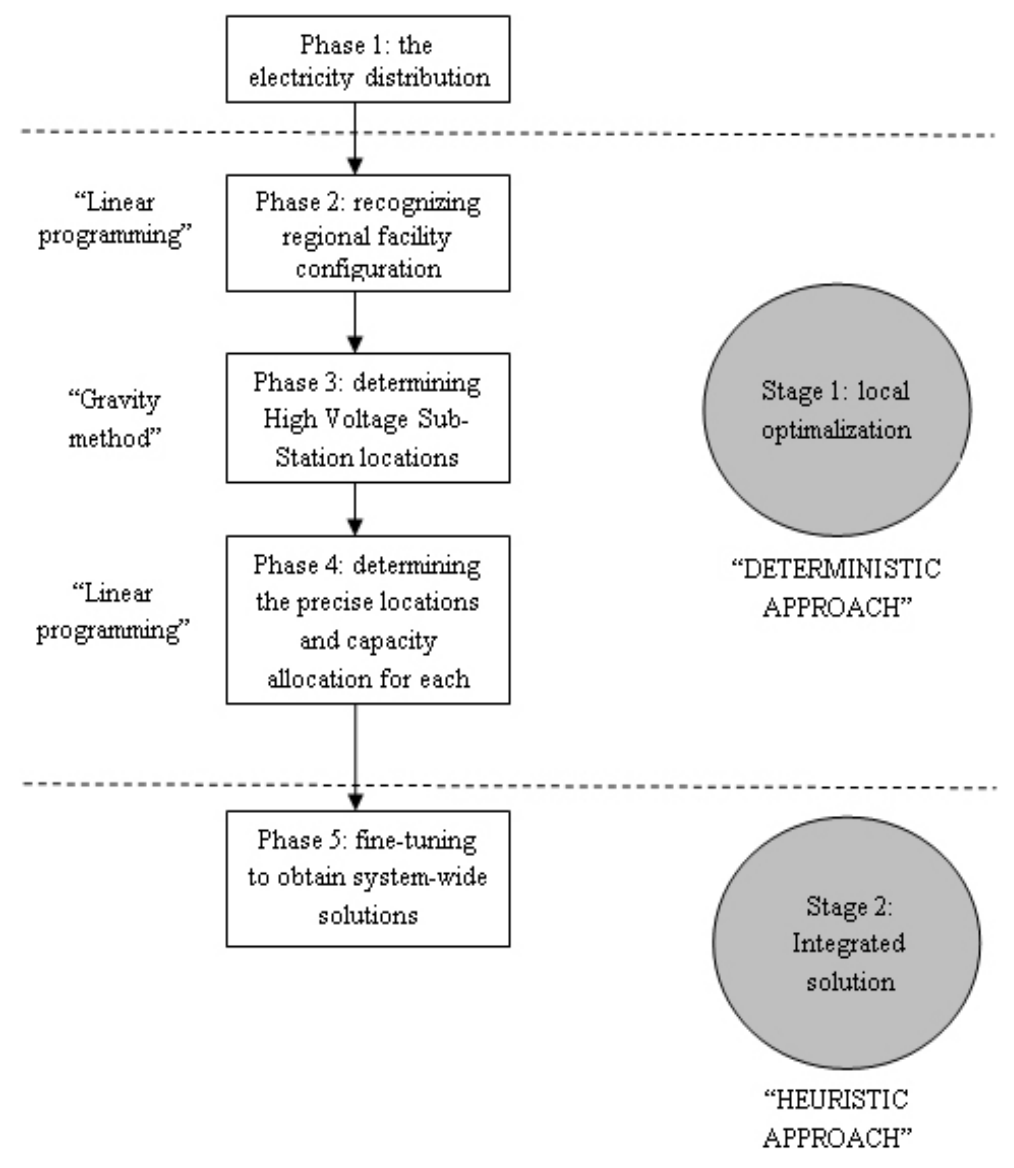

Figure 3. Distribution network decisions within a closed-loop supply chain 
As depicted in Figure 3, the decision is started by defining strategy of the supply chain. The purpose is to define what capabilities the supply chain must have to support the targeted electrification ratio for households within the JBN area (which is officially determined by the Indonesia Ministry of Energy and Mineral Resources). As this strategic decision must be implemented in all the JBN areas, then each local (currently five locals) establishes local optimization analysis to assign power stations in their lowest operating costs. For these phase one and two, the linear programming model is aimed to seek minimum costs of both transmission and power generating costs of the power plants (adapted from Chopra \& Meindl, 2016). Obviously the linear programming model, as presented in Equation 2, is different from the existing priority rules, which only concerns with power generating cost of each power plant (see The Ministry of Energy and Natural Resources, 2017):

$$
\begin{aligned}
& \operatorname{Min} \sum_{i=1}^{n} f_{i} y_{i}+\sum_{i=1}^{n} \sum_{j=1}^{m} c_{i j} x_{i j} \\
& \text { s.t. } \\
& \sum_{i=1}^{n} x_{i j}=D_{j}, j=1, \ldots, m \\
& \sum_{j=1}^{n} x_{i j} \leq K_{i} y_{i}, i=1, \ldots, n \\
& y_{i} \in\{0,1\}, i=1, \ldots, n
\end{aligned}
$$

Description: $\mathrm{n}$ (Number of power plant locations); $\mathrm{m}$ (Number of demand points); Dj (Demand from demand point j); Ki (Potential capacity of power plant i); fi (Power generating cost of keeping power plant $i$ open); cij (Cost of producing and delivering one unit from power plant $\mathrm{i}$ to demand point $\mathrm{j}$ ); yi ( 1 if power plant is located at site i, 0 otherwise); xij (Transmitted electricity from plant site $i$ to demand point $j$ ).

From the outset, the model of analysis (Figure 3) has different strategy in designing the electricity supply network as compared to the existing priority rule strategy. The former aims to minimize both power plant fixed costs and and the transmission costs whereas the priority rule only focuses on the utilization of the power plants with the lowest costs in power generation. It is apparent that priority rule is easy to implement as it only concerns with single decision; that is to spot power plants with lower cost, but this simple rule may lead to redundant supply problem as described in the previous discussion.

Phase three is to determine desirable sites of the local High-Voltage Sub-stations (HVS) to transmit electric supply from each local power plant, as indicated from the previous phase, to the demand points. Simple gravity location model is used to perform the analysis. Phase four is determining the precise locations of the Substations in each region. The sub-station configuration decision is also important in the analysis because it determines the transmission costs in the supply network. Both phase three and four of the analysis are known as "network optimization" analysis (Chopra and Meindl, 2016).

Given that the five local optimization analyses do not provide a system-wide solution, as performed in phase one to phase four, then it should be followed by a consolidated analysis for all the five local optimal solutions. The consolidated analysis is accomplished through a heuristic approach in order to obtain more efficient facilities to be employed within the system (not viewed from regional basis optimality), and to reallocate facility configuration either to reduce or to enhance electric supply. In the stage of analysis, the initial solutions of all five local optimal solutions are evaluated: if there is redundant utilization of the power plants (i.e. one power plant may serve too many demand points for all the five regions), then the previously unutilized power plants are selected to recover the supply. After this consolidation process is completed, the new facility configuration will be recalculated (using the above mentioned analytical tools) to convince that the lowest possible costs are attained. The recalculation for the consolidated solution is also intended to confirm whether total demand in the system is already met. The final step of this system-wide analysis is to evaluate whether the network needs (1) additional supply or (2) reducing electric supply because of the under- or oversupply condition. If the previous consolidated solution suggests additional electricity supply, then all power plants that are not included in the solution will be reevaluated: the more efficient power plants are selected to supply the network. On the other hand, if the initial consolidated solution indicates over supply condition, then power plants with higher inefficiency will be removed from the system. Thus power plants with higher efficiency are expected to serve the network. 
In testing the proposed model, Table 4 provides brief explanation on how the priority rule may yield less efficient solution as compared to the model. In the illustrative example there are 5 demand points (area A, $\mathrm{B}, \mathrm{C}, \mathrm{D}, \mathrm{E}$, and F respectively) with their corresponding electricity suppliers. Power plants at each demand point have a total supply capacity of 20 Mega-Watts. The power plants are varied in their power generating costs and are expectedly to supply their corresponding demand points, with the demand range from 2 to 12 Mega-Watts. It is assumed that transmission costs per Mega-Watts between supply locations and demand points are set differently. Based on the information, it is possible to prove whether the power supply configuration derived from the existing priority rule has a problem in targeting cost efficient supply. This is contrary to the fact that such approach is officially expected to provide the lowest possible supply (the Indonesia Ministry of Energy and Natural Resources, 2017).

The aim of priority rule, if it is implemented to the situation, is to assign the lowest possible cost of the power plants. Power plants in Area F (\$2,200 of total generating cost) are given the first priority, and all plants in Area B ( $\$ 3,500$ generating cost) should be the next priority. Thus the power plants located at Area $F$ will be supplying Area A (12 Mega-Watts) and Area B to $\mathrm{E}$ (2 Mega-Watts to each area). The remaining Area F (2 Mega-Watts electricity demand) will be supplied from the plants at Area B. Total power generating cost will be $\$ 2,200+\$ 3,500$ or $\$ 5,700$. However, in reality, total supply costs derived from the priority rule solution when transmission cost is included in the computation are $\$ 25,494$ (the transmission cost is substantial in the example, thus it should be included in the computation). In sum, if the sizeable transmission cost is not considered in the calculation, the total $\$$ 5,700 cost will be mistakenly concluded.

On the other hand, if the analysis employs Equation 2, that is to include both power generation and transmission costs, the solution yields different supply design. Power plants at Area E supply Area A(12 MegaWatts), Area B (2 Mega-Watts), and Area C (2 MegaWatts). Further, power plants at Area B will serve three demand points, D, E, and F with 2 Mega-Watts supply for each area. The supply network yields \$ 19,546 supply cost which is lower than if it is determined by priority rule. From the description it is obvious that the existing priority rule cannot afford its objective, that is to achieve the lowest possible cost of supply. Higher supply cost, as resulted from priority rule, may also indicate higher redundancy in the utilization of supply facilities (excess supply of plants at B area if employing priority rule is $18 \mathrm{MW}$, whereas if employing the proposed model is $14 \mathrm{MW}$ ). However we speculate that if the transmission cost is relatively insignificant as compared to the power generating cost, the priority rule may exhibit better solution (during the research, there was no evidence that JBN concerned with the transmission cost - see Table 3). The substantial effect of both power generation and transmission costs implies higher need of coordinating modes among power plants, sub-stations, and transmission lines. One cannot assign any power plant to operate just because the plant utilize lower energy without considering supply configuration in the system. Once the analysis has determined the supplying power plants, the next decision is to assign the High Voltage Sub-stations to transmit power from the plants to the demand points.

Table 4. Electricity supply in closed loop system (Chopra and Meindl, 2016)

\begin{tabular}{|c|c|c|c|c|c|c|c|c|}
\hline \multirow{2}{*}{$\begin{array}{l}\text { Supply/ Power } \\
\text { Plants Locations* }\end{array}$} & \multicolumn{6}{|c|}{ Transmission Cost per Mega-Watts (\$ 000) } & \multirow{2}{*}{$\begin{array}{l}\text { Power } \\
\text { Generating } \\
\text { Cost (\$ 000) }\end{array}$} & \multirow{2}{*}{$\begin{array}{l}\text { Supply } \\
\text { Capacity } \\
\text { (Mega-Watts) }\end{array}$} \\
\hline & Area A & Area B & Area C & Area D & Area E & Area F & & \\
\hline $\mathrm{A}$ & 1,675 & 400 & 685 & 1,630 & 1,160 & 2,800 & 7,650 & 20 \\
\hline B & 1,460 & 1,940 & 970 & 100 & 495 & 1,200 & 3,500 & 20 \\
\hline $\mathrm{D}$ & 1,925 & 2,400 & 1,425 & 500 & 950 & 800 & 5,000 & 20 \\
\hline $\mathrm{E}$ & 380 & 1,355 & 543 & 1045 & 665 & 2,321 & 4,100 & 20 \\
\hline $\mathrm{F}$ & 922 & 1,646 & 700 & 508 & 311 & 1,797 & 2,200 & 20 \\
\hline Demand & 12 & 2 & 2 & 2 & 2 & 2 & & \\
\hline
\end{tabular}

* One or more power plants can be established at a demand point. 
The brief example also indicates that data aggregation, as shown by the clustered demand points (by five area) and the clustered power plants (within each area), may be substantial issue in the network design decision. The literature review shows that forecast demand is expectedly more accurate at the aggregate level (as shown in the second stage of the proposed Two Stage Analysis - see Figure 3) because of the reduction in variability achieved through aggregation (Ballou, 2004; Simchi-Levi et al. 2004; Chopra and Meindl, 2016). The premise gives the reason on why the proposed example does not employ the original data to solve the sistem-wide problem. Ballou (2004) argues that aggregating data (as performed by establishing several local optimals) into about 150 to 200 demand points usually results in no more than 1 percent error in the estimation of the total costs. This implies that the size of each supply area will affect the aggregate decision for overall supply chain system.

Implementation of the system-wide analytical model, through the proposed two stage decision, may yield a unique information that some power plants have bigger opportunities to be selected, even though their locations are far from the demand points. This implies that those power plants (and their corresponding transmission lines) have higher efficiency among others in the closed loop system. Above all, the information may be deemed as a signal to initiate a system-wide improvement program for the power plant operations. The power plants efficiency map that is derived from the dual stage analytical method may be as reference of the program. Once the P2B (the PLN control center) collects daily data of the power plant utilization in the network, then they can establish a "historical efficiency map" of the supply system.

In line with the current Indonesia government policy to expand the power plant capacity to cover the country increasing electricity demand, the "historical efficiency map" will be a valuable reference to sustain the program. The information derived from the "historical efficiency map" may guide the expansion plan if the program has main focus on electric steam power plant establishment, because the expansion strategy would yield supply network with high power plant costs. Given the country mineral resources, the expansion strategy seems logical as Indonesia is one of the world's top coal producers in 2015 (IEA Key World Energy Statistics, 2016). In 2015 Indonesia was 471 metric-tonnes coal producer (out of the world total coal production of 7,925 metrictonnes). The opportunity of operating supply network with high power plant cost in such circumstances could be lowered by implementing the proposed dual stage analysis in the electricity distribution planning. The decision whether or not establishing new power plants (and their transmission lines) will exhibit better decision if "efficiency history" of the supply system has already been available in advance.

\section{Managerial Implications}

The article encouraged managers to focus on the consolidated decision following the local optimization analysis when dealing with the redundant supply issue. The article also portrayed the possibility of mistaken conclusion on efficient supply when transmission costs were ignored in a CLSC design decision analysis, as exhibited in the Indonesia electricity supply network

\section{CONCLUSIONS AND RECOMMENDATIONS}

\section{Conclusions}

Indonesia electricity distribution system could not rely on the existing priority rule policy to attain the lowest possible supply cost. System-wide analysis should be implemented in designing the Indonesia electricity distribution network, To do so, a dual stage model of analysis was proposed to obtain a system-wide solution. The local optimization stage followed by a consolidated analysis (through a heuristic approach) was the proposed decision making tool.

\section{Recommendations}

The decision making model as performed in the article expectedly could encourage research in other supply systems with closed loop networks, such as water supply system and gas supply for households. It is obvious that those supply networks would have different characteristics in determining their supply and transmission costs as well as defining their local optimization when compared to the electricity supply characteristic as presented in this article. 


\section{REFERENCES}

Ballou RH. 2004. Business Logistics / Supply Chain Management. 5th edition. New Jersey: Pearson Education, Inc.

Chopra S. 2003. Designing the Distribution Network in A Supply Chain. Transportation Research Part E 39: 123 - 140 .

Chopra S, Sodhi MS. 2004. Managing Risk to Avoid Supply-Chain Breakdown. MIT Sloan Management Review, Fall 2004

Chopra S, Meindl P. 2016. Supply Chain Management: Strategy, Planning, and operation. 6th edition. New York: Pearson Education, Inc.

Corley KG. \& Gioia DA. 2004. Identity ambiguity and change in the wake of corporate spin-off. Administrative Science Quarterly 49: 173 208.

Fleischmann et al. 1997. Quantitative models for reverse logistics: a review. European Journal of Operational Research 103:1 - 17.

Fleishmann M, Krikke HR, Dekker R, Flapper SDP. 2000. A characterization of logistics networks for product recovery. The International Journal of Management Science 28: 653 - 666.

Gioia DA, Corley KG, Hamilton AL. 2012. Seeking qualitative rigor in inducting research: notes on the gioia methodology. Organizational Research Methods 16(1): 15 - 31.

Guide JrVDR. 2000. Production planning and control for remanufacturing: industry practice and research needs. Journal of Operations Management 18: $467-483$.

Guide Jr VDR, Jayaraman V, Linton JD. 2003. Building contingency planning for closed loop supply chains with product recovery. Journal of Operations Management 21: 467 - 483.

Heizer J, Render B, Munson C. 2017. Operations Management: Sustainability and Supply Chain Management. 12th edition. Essex: Pearson Education Limited.

IEA Key World Energy Statistics. 2016.

Kumar S,Yamaoka T. 2007. System dynamics study of the Japanese automotive industry closedloop supply chain. Journal of Manufacturing Technology Management 18(2): 115 - 138.

Morana R. Seuring S. 2011. A three level framework for closed loop supply chain management - linking society, chain and actor level. Sustainability 3: $678-691$.
Rakhman A, Machfud, Arkeman Y. 2018. Kinerja manajemen rantai pasok dengan menggunakan pendekatan metode Supply Chain Operation Reference (SCOR). Jurnal Aplikasi Bisnis dan Manajemen 4(1): 106 - 118.

Schultmann F, Engels B, Rentz O. 2003. Closed-loop supply chains for spent batteries. Interfaces 33(6): $57-71$.

Shimchi-Levi D, Kaminsky P, Simchi-Levi E. 2004. Managing The Supply Chain: Definitive Guide for The Business Professional. The McGrawHill Companies, Inc. New York.

Souza GC. 2013. Closed-loop supply chains: a critical review and future research. Decision Sciences 44(1): $7-38$.

The Indonesia Ministry of Energy and Natural Resources Decree No. 3 / 2007. Guidelines in Managing Electricity Supply In Java, Madura, and Bali. Jakarta: The Indonesia Ministry of Energy and Natural Resources.

The Indonesia Ministry of Energy and Natural Resources. 2015. Guidelines in Electricity Supply for 2015 - 2024. Jakarta: The Indonesia Ministry of Energy and Natural Resources.

The Indonesia Ministry of Energy and Natural Resources. 2016. Guidelines in Electricity Supply for 2016 - 2025. Jakarta: The Indonesia Ministry of Energy and Natural Resources.

The Indonesia Ministry of Energy and Natural Resources Decree No. 12 / 2017. 2017. Guidelines in the Utulization of Renewable Energy for Power Plants. Jakarta: The Indonesia Ministry of Energy and Natural Resources.

Weltz P, Seitz M. 2005. Business models and closedloop supply chains: a typology. Supply Chain management: An International Journal 10(4): $249-251$.

Winkler H. 2011. Closed-loop production system - a sustainable supply chain approach. CIRP Journal of Manufacturing and Technology 4: 243 - 246.

Yin RR. 1981. The case study crisis: some answers. Administrative Science Quarterly 26(1): 58 65.

Yin RK. 2009. Case Study Research: Design and Methods. 4th Edition. Thousand Oaks, California: SAGE Publication, Inc. 